\title{
THE STRATEGY OF SCHOOL LITERACY CULTURE IN ELEMENTARY SCHOOL
}

\author{
Dyah Putri Fadillah ${ }^{1}$, Istikomah ${ }^{2}$ \\ ${ }^{1,2}$ Universitas Muhammadiyah Sidoarjo, Indonesia \\ Email: dyahputri660@gmail.com¹, istikomah1@umsida.ac.id ${ }^{2}$
}

Received: 12-07-2021

Revised: 20-09-2021

Accepted: 16-10-2021

\begin{abstract}
Abstrak
Tujuan Penelitian ini adalah untuk mengetahui bagaimana strategi pembudayaan Gerakan Literasi Sekolah di SDN Bubutan IV Surabaya. Penelitian ini menggunakan metode diskriptif kualitatif. Teknik pengumpulan data menggunakan observasi, wawancara dan studi dokumentasi. Teknik analisis menggunakan reduksi data, display data, dan penarikan kesimpulan. Uji keabsahan data dengan triangulasi sumber. Hasil penelitian dapat disimpulkan bahwa strategi pembudayaan Gerakan Literasi Sekolah sudah cukup baik dengan (1) mengondisikan lingkungan fisik dengan adanya pojok baca dan karya peserta didik terpajang di sekitar lingkungan sekolah, (2) mengondisikan lingkungan sosial dan afektif dengan memberikan reward kepada peserta didik, adanya peringatan hari besar dan nasional terintegrasi dengan pembelajaran literasi, dan (3) mengondisikan lingkungan akademike dengan membiasakan membaca 15 menit, adanya Tim Literasi Sekolah dan mempunyai perpustakaan dengan fasilitas yang mewadabi.
\end{abstract}

Kata Kunci: Strategi, Pembudayaan, Gerakan Literasi Sekolah

\begin{abstract}
:
The purpose of the study is to know how the implementation strategies in SDN Bubutan IV Surabaya. The descriptive qualitative method is used in this analysis. The collecting data technique is using data reduction, data display, and conclusion drawing. The data validity test is using source triangulation. The result of the study showed that the school literacy movement strategies are already successful with (1) conditioned physical environment with mini-libraries in each classroom and student artworks around school areas, (2) conditioned the social environment as an effective model by giving rewards toward students, there is also an activity to celebrate a national holiday that integrated with literacy learning, and (3) conditioned the academic environment with an accustomed student to read 15 minutes, the existence of school literacy team and having a library with proper facilities.
\end{abstract}

Keywords: Strategy of school, Cultivation, School Literacy Movement 


\section{INTRODUCTION}

Today's Indonesian people are required to be "literate" in technology and able to adapt to the latest and follow the developments of the times or "present" globally in the 21 st century. The literacy rate of the Indonesian people according to data from the UNDP (United Nations Development Program) in 2014 has reached $92.8 \%$ for the youth category and $98.8 \%$ for the adult category ${ }^{1}$. Seeing these results, the illiteracy rate in Indonesia is very low. Indonesian people, in general, cannot take advantage of these conditions properly. The 2012 Program for International Student Assessment (PISA) conducted tests on 15-year-olds, showing that Indonesians are ranked 64th with 65 countries $^{2}$. This data is in line with data from UNESCO (2012) which reveals that the reading habit of the Indonesian people is only one in a thousand people who have an interest in reading. This situation is worrying because reading skills and abilities are the beginning of the acquisition of knowledge, skills, and the formation of students' attitudes

Seeing this problem, the government needs to create a strategy to improve students' reading skills. The government formulates activities that can improve reading abilities and skills by making a breakthrough called the School Literacy Movement, which is abbreviated as GLS. The School Literacy Movement formed by the Ministry of Education and Culture Anies Baswedan is very helpful in carrying out the main tasks and functions of the Ministry of Education and Culture. The School Literacy Movement is an effort to make schools a learning organization that has a comprehensive and sustainable lifelong reading and writing culture, thus making schools fun, knowledgeable, caring, and virtuous. There are three stages of implementing the School Literacy Movement, namely: first, is the refraction of fun reading activities, secondly, the development of student's reading interest to improve literacy skills, and third literacy-based learning ${ }^{3}$. The first step for implementing the program is to familiarize students with reading, then development and learning. Students will get used to reading and can make reading a hobby, by getting used to reading from an early age and continuously. Get used to reading from an early age and repeatedly the stages that need to be instilled from the start ${ }^{4}$.

Students at school can be facilitated by starting the habit of reading from an early age. The School Literacy Movement can be entrenched by involving components that can support the implementation of these activities. Each component requires a strategy so that the School Literacy Movement can become entrenched. Components within the school include 1. Principal; 2. Class Teacher; 3 Parents; 4. Education staff and 5. community ${ }^{5}$. The principal

1 Muhamad Sadli dan Baiq Arnika Saadati, "ANALISIS PENGEMBANGAN BUDAYA LITERASI DALAMMENINGKATKAN MINAT MEMBACA SISWA DI SEKOLAH DASAR,” Jurnal Pendidikan dan Pembelajaran Dasa 6, no. 2 (2019): 2-4.

2 Ashar Hidayah, "PENGEMBANGAN MODEL TIL(THE INFORMATION LITERACY) TIPE THE BIG6DALAM PROSES PEMBELAJARAN SEBAGAI UPAYA MENUMBUHKAN BUDAYA LITERASI DI SEKOLAH," Jurnal Penelitian dan Penalara 4, no. 1 (2017): 2.

3 Ekol Pambudianto, "Literation Culture of Student Literature in Industrial Revolution 4.0," Journal of Intensive Studies on Language, Literature, Art, and Culture 3, no. 2 (2019): 2-8.

${ }^{4} \mathrm{Li}$ Wang, "Curriculum and Curriculum Integration of Information Literacy in Higher Education," dalam Developing People?s Information Capabilities: Fostering Information Literacy in Educational, Workplace and Community Contexts, vol. 8, 0 vol., Library and Information Science 8 (Emerald Group Publishing Limited, 2013), 31-49, https://doi.org/10.1108/S1876-0562(2013)0000008007.

5 Yunus Abidin, "Developing literacy learning model based on multi literacy, integrated, and differentiated concept at primary school," Jurnal Cakrawala Pendidikan 36, no. 2 (2017): 156-66; Anthony Pellegrini dan Lee 
controls management in schools and monitors learning activities in schools. The class teacher is a facilitator for students to provide direction in the implementation of a lesson. Parents are caregivers and provide the main and most important example for students in student literacy activities. Educational staff for example librarians who provide services to students in supporting learning activities. Communities in the surrounding environment where students are usually made to play can affect the process of implementing the program. How each school component has a strategy that is applied to students to cultivate the School Literacy Movement ${ }^{6}$.

The school community's strategy plays an important role in providing support for the implementation of the School Literacy Movement. Because all activities if there is no support and persistence with one another, these activities cannot run smoothly. In the City of Surabaya, which was declared by the Mayor of Surabaya, Mrs. Tri Rismaharini, to become a Literacy City on Friday, May 2, 2014, at Taman Surya in conjunction with the commemoration of National Education Day published by Antara News. ${ }^{7}$ "The realization of a literacy city is also part of my commitment to not only focus on building infrastructure, but also focus on the human development index in Surabaya," he said. This support is very helpful in the implementation of the School Literacy Movement program. It's just a matter of how schools are places to learn and apply knowledge. Especially in elementary schools, it is very necessary to get used to the implementation of the School Literacy Movement, because when students are still in elementary school, it is very easy to accept and store memories in long-term memory.

Schools can be at the forefront by cultivating literacy, ${ }^{8}$ convey how the strategy to cultivate positive literacy in schools, namely: (1) creating a literacy-friendly physical environment is something that school residents need to pay attention to. Thus, the physical environment should be friendly, comfortable, and conducive to the implementation of learning. Schools that support literacy culture can be seen from these conditions: students' works are displayed in the school environment, students' works are continuously replaced so that other classes also get the opportunity to display their work. Not only that, books and other reading materials can be easily found in reading corners in classrooms, teachers' rooms, offices, principals' offices, and other places in the school environment. The principal's office is better if it displays the works of students so that they can give a good impression on the development of literacy culture. (2) making the social and affective environment into a literate model of communication and interaction, through interaction and communication activities of all school components. This activity can be formed by giving an award to students who get an achievement throughout the year. Overseas schools, giving achievement awards once a week

Galda, The Development of School-Based Literacy: A Social Ecological Perspective (London: Routledge, 2017), https://doi.org/10.4324/9781351236263.

${ }^{6}$ Helenrose Fives dkk., "Developing a Measure of Scientific Literacy for Middle School Students," Science Education 98, no. 4 (2014): 549-80, https://doi.org/10.1002/sce.21115; Jessica Whitley dkk., "Promoting Mental Health Literacy Among Educators: A Critical Aspect of School-Based Prevention and Intervention," dalam Handbook of School-Based Mental Health Promotion: An Evidence-Informed Framework, for Implementation, ed. oleh Alan W. Leschied, Donald H. Saklofske, dan Gordon L. Flett, The Springer Series on Human Exceptionality (Cham: Springer International Publishing, 2018), 143-65, https://doi.org/10.1007/978-3-319-89842-1_9.

7 Andika Wahyu, "Surabaya deklarasikan sebagai kota literasi," 2014.

${ }^{8}$ Mulyo Teguh, "Gerakan Literasi Sekolah Dasar," Jurnal Pendidikan Dasar Flobamorata 1, no. 2 (2020). 
when the ceremony has been carried out regularly. Not only academic but courteous attitude is an achievement of students. Thus every student gets the opportunity to get a reward from the school. These activities can be realized in the form of festivals, poster competitions, and other activities. Principals should take an active role in cultivating the school literacy movement, by inviting teachers and staff to collaborate ${ }^{9}$. In this way, everyone can follow and be involved in their respective fields. Parental support plays an important role in cultivating the school literacy movement. (3) making the school an academic environment with a culture of literacy, paying attention to the physical, social, and affective environment can be built if the academic environment goes well. This can be seen from the planning and implementation of the literacy movement in schools. The principal as a leader in the school can create a literacy team. Furthermore, this team is tasked with planning and assessing the program. The existence of a school literacy team will create a conducive atmosphere, where all school members are enthusiastic about implementing the School Literacy Movement ${ }^{10}$. One of them is to carry out reading silently and the teacher reads the book aloud for 15 minutes before the lesson. To support the ability of teachers and staff, they need to be allowed to participate in education staff training programs to increase understanding of literacy programs, their implementation, and their implementation ${ }^{11}$.

This study aims to explore how to cultivate the Literacy Movement at SDN Bubutan IV Surabaya because there are several things that I want to know where the SDN Bubutan IV Surabaya school became a National Literacy Pilot Elementary School in 2015, published by Surya $^{12}$. SDN Bubutan IV Surabaya also won 1st place in 2013 in a library competition held by the Mayor of Surabaya and became a destination for other schools, many visitors from outside the city, outside the province, have even visited schools from abroad to find out how the Literacy Culture at SDN Lathe IV Surabaya.

\section{METHOD}

The research was carried out at SDN Bubutan IV Surabaya City, located near the Science Village of Surabaya. This school was once a National Literacy School in 2015 and won one of the best libraries in Surabaya in 2013. Not only that, this school has become a barometer of Literacy in the City of Surabaya, this is shown by SDN Bubutan IV as a school that has always been a destination for students. visitors to other schools from out of town and

9 Mohamad Iwan Fitriani dan Mohammad Viktor Farid Hakim, "Principal Leadership Patterns in Collaborating With School Committee," Nidhomul Haq: Jurnal Manajemen Pendidikan Islam 6, no. 1 (21 Mei 2021): 194-205, https://doi.org/10.31538/ndh.v6i1.1384; Ahmad Tajudin dan Andika Aprilianto, "Strategi Kepala Madrasah..Dalam Membangun Budaya Religius Peserta Didik," Munaddhomab: Jurnal Manajemen Pendidikan Islam 1, no. 2 (25 September 2020): 101-10, https://pasca.jurnalikhac.ac.id/index.php/munaddhomah/article/view/34.

${ }^{10}$ Rony, "Urgensi Manajemen Budaya Organisasi Sekolah Terhadap Pembentukan Karakter Peserta Didik: The Urgency of School Organizational Culture Management Against Character Building Students," Tafkir: Interdisciplinary Journal of Islamic Education 2, no. 1 (10 Februari 2021): 98-121, https://doi.org/10.31538/tijie.v2i1.26.

11 Dewi Utama Faizah, Panduan Gerakan Literasi Sekolah di Sekolah Dasar (Jakarta: Direktorat Jenderal Pendidikan Dasar dan Menengah Kementerian Pendidikan dan Kebudayaan, 2016); Adib Rifqi Setiawan, "Pendidikan Literasi Finansial Melalui Pembelajaran Fiqh Mu'āmalāt Berbasis Kitab Kuning," Naz̧hruna 3, no. 1 (1 Maret 2020): 138-59, https://doi.org/10.31538/nzh.v3i1.522.

12 Magdalena Fransilia, "Percontohan Literasi Nasional, Perpustakaan SDN Bubutan IV Surabaya Banyak Dikunjungi," 2015. 
even from outside the island. The time of this research was carried out approximately from March to April 2017 in approximately two months.

The research carried out is qualitative research with a descriptive type to describe according to the nature, the character of a particular individual, organization, or group, so that it is easy to determine the frequency of the relationship between a symptom and symptoms that exist in the community ${ }^{13}$. In this study, the researcher wants to describe how the strategies implemented by the school are an effort to cultivate the School Literacy Movement. Researchers use descriptive qualitative methods because they want to see authenticity and existing conditions as a whole (holistic), dynamic, full of meaning, and complex ${ }^{14}$. This study does not use a hypothesis, but rather finds out, presents, and develops the concept of school strategy in cultivating the School Literacy Movement. This research is an in-depth discussion of events in circumstances that will be able to reveal and understand something ${ }^{15}$ concerning this research is the school's strategy in cultivating the School Literacy Movement at SDN Bubutan IV.

In this study, researchers need data in the form of (1) Words and actions from informants or resource persons which include, principals, classroom teachers, employees, librarians, students, and parents. (2) Documents/Sources of other written data in the form of archives, documents of academic and non-academic achievements as well as other supports related to cultivating the school literacy movement at SDN Bubutan IV Surabaya. (3) Photos used to support data related to efforts to cultivate the School Literacy Movement at SDN Bubutan IV Surabaya. The category of photos taken consists of photos taken by other people that can describe the answers to research problems.

Data collection is a primary data process for research purposes. In this study, the technique used to collect data consists of (1) in-depth interviews, which is a method of collecting data through communication, namely through dialogue or independent relationships between data collectors (interviewers) and data sources (informants). Questions that have been arranged related to the application of administrative sanctions for returning library materials will be questioned when the research is carried out, (2) The form of observation in this study is carried out openly both in the teacher's secretariat room, in the classroom, and in the library, which is in every place that is observed. very supportive of efforts to civilize the literacy movement, (3) study documentation, in the process of this research, researchers can document data on school activities in cultivating the School Literacy Movement, including (a) Profile of SDN Bubutan IV Surabaya to find out the history of the school; (b) Learning Process Activities carried out inside and outside the classroom; (c) Library Visit Activities; (d) School Infrastructure that can support the learning process to cultivate literacy, (e) Extracurricular activities which are non-academic activities in building students' hard skills. The results of the documentation are to strengthen the research carried out.

In this case, a study needs to develop a design for the preparation of an instrument known as the "grid". The instrument arrangement grid shows the relationship between the variables studied and the data source from which the data was taken, the method used and the

\footnotetext{
${ }^{13}$ Koentjaraningrat, Metodologi Penelitian Masyarakat (Jakarta: Gramedia, 1993).

14 Sugiyono, Memahami Penelitian Kualitatif (Bandung: Alfabeta, 2005).

${ }^{15}$ Sulistyo Basuki, Metode Penelitian (Jakarta: Wedatama Widya Satra, 2006).
} 
instrument prepared. So the research on school strategies in cultivating the School Literacy Movement at SDN Bubutan IV Surabaya has made a grid of research instruments as follows: (1) schools condition a literacy-friendly physical environment (2) make the social and affective environment a model of communication and interaction with a culture of literacy (3) make the school an academic environment with a culture of literacy.

After the data from the research results were obtained with various data collection techniques, the next step was to process the data. Activities in data analysis are (1) Reduction is a process of selecting, summarizing, and transforming rough data from field findings. Through data reduction, we can summarize, choose things that are focused on school strategies in literacy culture. Thus the reduced data will provide a clearer picture so that it is easier for researchers to collect further data; (2) Data display or data analysis is data display or data presentation. To look intact, the results of data reduction are organized into a certain form. According to Sugiyono, the display of data systematizes the main points of information according to the theme and pattern of problems or the School Strategy for acculturating the School Literacy Movement. Data obtained through interviews, observations, and documentation studies will be displayed in narrative form to make it easier to understand and can easily collect further data; and (3) verifying or drawing conclusions, drawing conclusions is done by looking at the whole process of research activities. To determine, it can be in the form of a description or description of an object that was previously not clear, casual or interactive relationships can be carried out. The conclusion can be said to be credible if it is supported by consistent and valid evidence.

In testing credibility, it is defined as examining data from various sources and various ways of collecting data that are carried out at various times. Triangulation is divided into three, namely source triangulation, data collection technique triangulation, and time triangulation. In this activity, the researcher uses source triangulation because it is felt that the researcher can test the credibility by examining the data obtained from several sources including; Principals, teachers, librarians, employees, students, and parents. The data that has been checked and analyzed for validity then produces a descriptive form of conclusion about the strategy of SDN Bubutan IV Surabaya in cultivating the School Literacy Movement.

\section{RESULTS AND DISCUSSION}

\section{Strategy for Cultivating School Literacy Movement}

Based on the information that has been obtained by the author from several guardians of students in Surabaya, that the majority of respondents gave responses to the author, if students are already at home, their interest in learning and reading decreases. Students are cooler with their world which always prioritizes playing big and playing. Under the results of interviews conducted by the author on a student's guardian said that "I prefer it if my child is in school and does online learning every day. Because if they don't go to school and there are no online teaching and learning activities, then my children are very happy and spend their time playing gadgets. Therefore, as a parent, I prefer that my child is given extra time to attend school even though he is online to avoid the time he spends playing big games." 
The statement that has been submitted by one of the guardians of the students has represented other guardians, that students at home prefer to spend their time playing big games or other things. In fact, with a lot of reading, and writing students have far more insight and new knowledge that previously had not been understood. Following Alberta's opinion that "if students can read and write, then these students can increase their knowledge and skills, think critically in solving problems, and communicate effectively that can develop their potential and participate in community life".

Some of the phenomena above can be concluded that, the importance of literacy for students to lead students to live in the future armed with a lot of knowledge to answer the challenges that will come.

\section{Cultivating School Literacy}

Cultivation is a process of achieving permanent results in the form of appreciation and all the knowledge and skills obtained through education so that the individual concerned can do or do something useful for his life or the lives of others ${ }^{16}$. Literacy culture is carried out on students not only when students are at school, but the school also needs help and encouragement from parents to apply reading and writing habits when students are at home, so students will get used to a situation that has a reading environment. as well as writing.

\section{DISCUSSION}

\section{Strategy for Cultivating School Literacy Movement at SDN Bubutan IV Surabaya}

From the results of this study, the focus will be on discussing the presentation of data about the strategy of civilizing the school literacy movement at SDN Bubutan IV Surabaya. Nopilda argues that strategy is the science of directing and planning activity in a large capacity and providing a stimulus to achieve goals and skill in managing a tactic or smart way to achieve a goal ${ }^{17}$. In this activity the researchers used interview techniques to collect data on informants by conducting interviews with school principals, TU employees, teachers, librarians, guardians of students, and students, also using observation sheets and documentation studies to support the acquisition of data or information that has been obtained.

Looking at the problems studied, it has been discussed in the previous chapter that the researchers conducted research referring to the strategy of cultivating the school literacy movement which pays attention to three aspects of school strategy according to Faiza et al, in the School Literacy Movement guidebook by conditions: (a) A literacy-friendly physical environment, (b) A social and affective environment with a literacy culture, (c) an academic environment with a literacy culture ${ }^{18}$.

This can be seen during interviews with informants/resources and the information collected can be concluded as a strategy for the culture of the School Literacy Movement at SDN Bubutan IV. The process of teaching and learning activities at SDN Bubutan IV

\footnotetext{
${ }^{16}$ I Ketut Seken, “Aspek Pembudayaan Dalam Pendidikan,” Jurnal Pendidikan dan Pengajaran IKIP Negeri Singaraja, 2018, 7.

17 Lisa Nopilda dan Muhammad Kristiawan, "GERAKAN LITERASI SEKOLAH BERBASIS PEMBELAJARAN MULTILITERASI SEBUAH PARADIGMA PENDIDIKAN ABAD KE- 21," Jurnal Manajemen, Kepemimpinan, dan Supervisi Pendidikan 3, no. 2 (2018): 218.

${ }^{18}$ Dewi Utama Faiza, Panduan Gerakan Literasi Sekolah (Jakarta: Direktorat Pembinaan Sekolah Dasar, 2016).
} 
Surabaya in cultivating the literacy movement has been instilled in students as early as possible. Following the school's vision which reads "Develop a culture of reading, curiosity, tolerance, cooperation, mutual respect, discipline, honesty, hard work, creative and independent". And supported by a statement by the principal as follows: "It won't take a while, Ms. And for babituation to students, starting from the beginning of entering school, they have been given literacy babituation."

"...starting this school consisted of four schools then it became two as if and now it has been merged into one school at SDN Bubutan IV Surabaya.

From the first time students set foot in SDN Bubutan IV, they will be accustomed to reading from an early age with facilities and a supportive atmosphere in carrying out learning activities. It is inseparable from the efforts made by the school in building good character and having a global perspective. The same thing was conveyed by Pak Haris as a librarian, here are the results of an interview with him: "From an early age, children start entering grades one to grade six to create a school with a literacy culture."

The School Literacy Movement is a breakthrough from the Ministry of Education and Culture to cultivate the character or behavior of students through the cultivation of literacy in schools which is manifested in the School Literacy Movement so that students become people who are broad-minded and can become the next generation of a superior nation. The initial stage of implementing the School Literacy Movement is to get used to reading activities for approximately 15 minutes. In fact, not only reading activities, at SDN Bubutan IV Surabaya many implement various literacy practices as conveyed by the principal in the interview results as follows: "Literacy is not just reading but understanding everything from low to bigh levels covering all aspects ranging from student character education, student mentality, student creativity are all considered and improved."

The school leader's statement explained that it was not just reading that was applied at SDN Bubutan IV Surabaya but after the students read than understood, explained again, and practiced in daily life. Mr. Khalim's statement as the principal of SDN Bubutan IV, Mrs. Nurul as a low-grade teacher, and Mrs. Endang as a librarian also conveyed the same thing. Here are the results of the interviews:

"Well, in our elementary school children start by reading, after reading children start thinking, then children start to be motivated, after that, they try and react immediately. This means that after this child reads "ob" it is read, for example, what is read about mother's love, after it is understood after understanding what mother's love means, they start to try to tell and apply it to their mother for the lower classes so they don't just read. There's another way to give songs, it's easiest for children to memorize songs, so from songs they can be understood and practiced/ applied at school. An example is about nutrition, for example, bealthy nutrition is related to the material from the theme book. We apply it to a nutrition exhibition that is held with students so that it is following the book with the theme of activities with parents so that children are not only given homework but also involve students being directly involved."

"Yes, I think the literacy movement at this school is quite good, judging from every day, we have a schedule of mandatory visits to the library. Then every morning it is mandatory to read a book before learning begins, it is mandatory to read 15 minutes. In addition, we also apply the existing curriculum to be applied to literacy. Mas Haris here as an officer from the Barpus also helps the children, for example, making what kind of crafts he must accompany there and he also gives directions to the children to always be diligent in reading." 
The point is to increase interest in reading, some people think that it is only with reading and writing activities, even students usually read under forced circumstances when they just open the book but don't read the book. By looking at it, of course, there are efforts and efforts to increase interest in reading. As stated by Mrs. Sari as a librarian and Mrs. Nurul as a low-grade teacher, she conveyed the following:

"For literacy, because the main thing is reading, so before learning at 0 hours it is customary to read books for about 15 minutes every day, that is for those who can read. For those who can't read, we teach them to draw, now the picture below has the initials B and then he continues the writing. Because the class is early so some can't read yet. So this way makes it easier for children to recognize them and can read from pictures."

A method that is applied does greatly affects how the child catches what is conveyed. Other techniques are in line with Mrs. Sari and Mrs. Nurul, the following was conveyed by Pak Haris as a librarian:

"Yes, I tried to enter the world of children, where I usually look like a clown, a puppet character, traditional clothes, and the main thing is to wear unique clothes "like that". So when children play in the library, they don't just read but are given a fairy tale and then the children are asked to retell it like that."

Activities like that need to be carried out in every lesson because to make learning not focused on one side only and not saturated. The same thing was conveyed by Mr. Adit as the student's guardian. Here are the results of the interview: "It's been a while, as far as I know, it's been a long time I've seen someone who becomes a clown and continues to wear strange clothes like that."

By looking at the explanation given by Mrs. Sari and Mr. Haris, the School Literacy Movement at SDN Bubutan IV has indeed been going well. To be more conditioned in cultivating the School Literacy Movement, a school needs to pay attention to the physical environment, affective social environment, and academic environment.

\section{Cultivating the School Literacy Movement at SDN Bubutan IV Surabaya Conditioning a Literacy Friendly Physical Environment}

Following the School Literacy Movement guidebook published by the Ministry of Education and Culture in 2016. According to Beers, et al. in Widartik, et al, in the book The Main Design of the School Literacy Movement explains how to condition a literacy-friendly physical environment ${ }^{19}$. Thus, the physical environment should be friendly, comfortable, and conducive to the implementation of learning. Schools that support literacy culture can be seen from these conditions: students' works are displayed in the school environment, students' works are continuously replaced so that other classes also get the opportunity to display their work. Not only that, books and other reading materials can be easily found in reading corners in classrooms, teachers' rooms, offices, principals' offices, and other places in the school environment. The principal's office is better if it displays the students' works so that they can give a good impression on the development of literacy culture.

At SDN Bubutan IV Surabaya, in creating a literacy-friendly physical environment by displaying the rich results of students in the classrooms, the walls of the stairs also contain pictures, wall magazines in each class, and student bathrooms with posters on them. Direct

19 Pangesti Wiedarti, Gerakan Literasi Sekolah, ed. oleh Desain Induk (Jakarta: Direktorat Jendral Pendidikan Dasar dan Menengah Kementrian Pendidikan dan Kebudayaan., 2016). 
display of work by students, scheduled changes to displays are made so that all students have the opportunity to display the work they have made. Because if there are students who do not have the opportunity to display the work, they will feel inferior and cry.

Each class also has a reading corner for students. There are various collections of textbooks as well as various general collections such as folklore, comedy, comics, and many others according to what students want. There is also filtering from the homeroom teacher when students collect reading books that they will read.

Reading books that are usually only found in the library, SDN Bubutan IV realizes this by providing a reading area which was in the corners of the classroom, also available in the headmaster's room and the prayer room. In every place that has a collection of books, there must also be reading books for visitors. In this case, SDN Bubutan IV cooperates with the surrounding environment to be able to visit the school library so that they can take advantage of existing facilities to help residents.

The principal is seeking a literacy-friendly physical environment that prioritizes dialogue with teachers, employees, and students. The principal also often goes around the classes and then invites students to always try to increase their interest in reading.

\section{Making the Social and Affective Environment a Literary Communication and Interaction Model}

According to Wiedarti, stated that schools carry out activities through interaction and communication with all school members ${ }^{20}$. This activity can be formed by giving an award to students who get an achievement. Not only academic but polite attitude is an achievement of students. Thus every student gets the opportunity to get a reward from the school. Principals also take an active role in cultivating the school literacy movement, by inviting teachers and staff to collaborate. And parental support plays an important role in cultivating the school literacy movement.

In carrying out the civilizing of the literacy movement at SDN Bubutan IV Surabaya, it proves that in making the social environment the role of literate communication and interaction by responding to students who excel in academic and non-academic fields, they are given a gift or award from the school or also from the class teacher. In giving rewards to students, each teacher has their way of dealing with their students. Rewards are also given to students every week and even every day according to their respective class teachers. It is intended that students do not feel forced to learn and to increase the enthusiasm of students in pursuing an achievement.

Commemorating major or national days at SDN Bubutan IV always hold activities that not only support the motor skills of students but also provide an activity that is integrated with the subject. Such as holding short story writing competitions, writing poetry in commemoration of Kartini's day, giving speeches about Indonesian Independence, and many more.

Conditioning a school environment to be literate communication and interaction, residents of SDN Bubutan IV Surabaya held an activity that was attended by all components

\footnotetext{
${ }^{20}$ Wiedarti.
} 
of educators in the school to exchange opinions and give each other and be given input, to establish good communication from the principal, teachers class, librarian and staff. This activity is carried out twice a month under the leadership of the principal. In terms of making a decision, the principal always conveys in advance to all teachers and employees to determine an activity to be carried out.

\section{Making Schools An Academic Environment With Literacy Culture}

According to Wiedarti, et al. The physical, social, and affective environment can be built if the academic environment goes well ${ }^{21}$. This can be seen from the planning and implementation of the literacy movement in schools. The principal as a leader in the school can create a literacy team. Furthermore, this team is tasked with planning and assessing the program. The existence of a school literacy team will create a conducive atmosphere, where all school members are enthusiastic about implementing the School Literacy Movement.

In cultivating literacy, of course, by carrying out reading activities silently and the teacher reading books aloud for approximately 15 minutes before the lesson takes place. To support the ability of teachers and staff, they need to be allowed to take part in education staff training programs to increase understanding of literacy programs, their implementation, and their implementation. ${ }^{22}$

In carrying out the civilizing of the Literacy Movement, SDN Bubutan IV Surabaya set up a special team tasked with preparing, implementing, and evaluating literacy activities in schools. The school literacy team has a management structure and has various tasks with the scope of literacy activities, for example: arranging a schedule for reading books, helping to manage the classroom reading corner, arranging activity in the field of literacy, and holding a selection for students to become school literacy ambassadors.

The activities of the School Literacy Movement in the early stages are habituation by getting used to reading books for at least 15 minutes a day. SDN Bubutan IV has library facilities that are very supportive of reading activities. Very good library management where there is a management structure, pleasant reading room, very supportive facilities. Activities at the SDN Bubutan IV library have a mandatory schedule for each class for learning in the library. In addition to reading books in the library, there are also storytelling activities, resume a book and then retell it, book review, there are also fairy tales from a librarian, the practice of cultivating catfish and solar panels directly, and watching video stories. The library which has a collection of more than 40,000 reading books is not only for students who use it but the surrounding community can also take advantage of the existing facilities in the library, because the SDN Bubutan IV Surabaya library has collaborated with residents in utilizing existing facilities.

In increasing understanding about the implementation of the School Literacy Movement, several teachers and school employees participated in training activities held by the local office.

\footnotetext{
21 Wiedarti.

22 Wiedarti.
} 


\section{Benefits of the School Literacy Movement for School Residents}

The School Literacy Movement at SDN Bubutan IV Surabaya has a lot of positive impacts on school residents, especially for students in improving abilities which are divided into three domains, namely the cognitive, affective, and psychomotor domains.

Discussing the cognitive domain is a domain related to the knowledge that involves brain activity. Students are provided with the habit of reading 15 minutes which is carried out at school, then the implementation of a scheduled library visit once a week. SDN Bubutan IV Surabaya habituation is carried out not only by reading books but also by using several strategies. Among them, giving fairy tales by dressing according to the story to be conveyed, such as wearing clown clothes, traditional clothes, simple clothes, and so on. Thus, students carry out reading according to their own will without any element of coercion, gain knowledge, insight, increase vocabulary and find out new information around them. The results obtained after students use books, there is an increase and learning progress.

The affective domain is something related to attitudes and manners that are carried out every day. The results of observations that have been carried out by researchers, SDN Bubutan IV Surabaya apply a strategy by giving a gift or reward to students who have academic and non-academic achievements, for example, based on students' stories that they can solve problems with friends or develop the ability to live together because they are inspired by the life stories of story characters. in the books they read. And students are given activities that involve collaboration between friends or groups to train students to communicate well with each other and respect what has been conveyed by their friends.

The psychomotor domain is a domain related to skills or related to physical activities. In the psychomotor domain or skills, SDN Bubutan IV Surabaya applies various strategies by involving all students, for example, activities carried out in the library as usual which are carried out reading activities then understanding and applying or making skills from what has been read. That way students get a lot of skills or certain activities that students can do based on ideas obtained from books that have been read.

\section{Obstacles and Overcoming Strategies}

The Socialization of the School Literacy Movement is Not Complete. Seeing the condition of SDN Bubutan IV Surabaya, which is currently a pilot school in literacy activities, many schools, agencies, and offices have visited schools. Thus, it is necessary to have a thorough understanding of the school community about the School Literacy Movement. The average teacher at SDN Bubutan IV Surabaya already knows but, some do not understand, especially for the parents of many students who do not know about the School Literacy Movement. Because parents also play an important role in supporting its implementation. Coping Strategy with the school holding its training by inviting speakers from outside, followed by all school components. Holding an agenda once a month inviting all teachers and guardians of students for meetings and socialization.

The second is about time constraints, the current headmaster of SDN Bubutan IV Surabaya is the PLT (executive) principal, so that in the 2019/2020 school year he leads two schools. The problem is the lack of direct monitoring and instructions regarding the 
implementation of the literacy movement in schools because he cannot always control the condition of the school. The strategy to overcome this, the principal is as a leader and in control. Thus, every morning before going to the other school, he always came to school to control and then always communicated with the teachers, especially with Pak Haris and $\mathrm{Bu}$ Endang who served as the Literacy Team at the school. So literacy activities in schools are still well monitored and can run smoothly.

Then the last is the third obstacle, when carrying out literacy activities in schools there is a need for preparation and preparation to carry out these activities. Because the School Literacy Team also doubles as a classroom teacher, it is constrained that there is no specific meeting agenda, just discussing when there will be activities. The strategy to overcome at the time of preparation required communication between members of the literacy team as conceptions of activities. That way the literacy team can always know the development of literacy in the school. Then, after a meeting with all school members, the School Literacy Team gathers to discuss literacy culture.

\section{CONCLUSION}

Based on the results of data analysis, it can be concluded that the strategy of acculturating the school literacy movement at SDN Bubutan IV Surabaya is as follows: (1) The achievement of a literacy-friendly physical environment by conditioning the school environment with reading corners in each class, in the principal's room, prayer room and gazebo. Many of the students' works are displayed in the classrooms, the teacher's room, and the principal's office. (2) Making the social and affective environment a model of communication and interaction with literacy culture, schools provide awards or rewards to students who have achievements. Prizes are given by the homeroom teacher or the principal at the time of the class and during the flag ceremony. There are also activities to commemorate major and national holidays that are integrated with literate learning. (3) School achievements by creating an academic environment with a literacy culture by carrying out reading non-lesson books for approximately 15 minutes, then student representatives take turns telling the story in front of the class. There is a special team that handles the activities of the School Literacy Movement which is usually called the TLS (School Literacy Team). The team helps organize and implement the literacy movement culture in schools. SDN Bubutan IV Surabaya has a library with very adequate facilities for increasing students' interest in reading. The school library is used by students with reading activities, there are also other activities such as storytelling, summarizing a book and then retelling it, book review, there are tales from a librarian, the practice of cultivating catfish and solar panels directly and watching video stories, the school library also collaborates with the surrounding community, making the existing facilities in the library not only used by students but also used by the surrounding community to read and enjoy the existing facilities. 


\section{REFERENCES}

Abidin, Yunus. "Developing literacy learning model based on multi literacy, integrated, and differentiated concept at primary school." Jumal Cakrawala Pendidikan 36, no. 2 (2017): 156-66.

Basuki, Sulistyo. Metode Penelitian. Jakarta: Wedatama Widya Satra, 2006.

Faiza, Dewi Utama. Panduan Gerakan Literasi Sekolah. Jakarta: Direktorat Pembinaan Sekolah Dasar, 2016.

Faizah, Dewi Utama. Panduan Gerakan Literasi Sekolah di Sekolah Dasar. Jakarta: Direktorat Jenderal Pendidikan Dasar dan Menengah Kementerian Pendidikan dan Kebudayaan, 2016.

Fitriani, Mohamad Iwan, dan Mohammad Viktor Farid Hakim. "Principal Leadership Patterns in Collaborating With School Committee." Nidhomul Haq : Jurnal Manajemen Pendidikan Islam 6, no. 1 (21 Mei 2021): 194-205. https://doi.org/10.31538/ndh.v6i1.1384.

Fives, Helenrose, Wendy Huebner, Amanda S. Birnbaum, dan Mark Nicolich. "Developing a Measure of Scientific Literacy for Middle School Students." Science Education 98, no. 4 (2014): 549-80. https://doi.org/10.1002/sce.21115.

Fransilia, Magdalena. "Percontohan Literasi Nasional, Perpustakaan SDN Bubutan IV Surabaya Banyak Dikunjungi," 2015.

Hidayah, Ashar. "PENGEMBANGAN MODEL TIL(THE INFORMATION LITERACY) TIPE THE BIG6DALAM PROSES PEMBELAJARAN SEBAGAI UPAYA MENUMBUHKAN BUDAYA LITERASI DI SEKOLAH." Jurnal Penelitian dan Penalara 4, no. 1 (2017): 2.

Koentjaraningrat. Metodologi Penelitian Masyarakat. Jakarta: Gramedia, 1993.

Nopilda, Lisa, dan Muhammad Kristiawan. "GERAKAN LITERASI SEKOLAH BERBASIS PEMBELAJARAN MULTILITERASI SEBUAH PARADIGMA PENDIDIKAN ABAD KE- 21." Jurnal Manajemen, Kepemimpinan, dan Supervisi Pendidikan 3, no. 2 (2018): 218.

Pambudianto, Ekol. "Literation Culture of Student Literature in Industrial Revolution 4.0." Journal of Intensive Studies on Language, Literature, Art, and Culture 3, no. 2 (2019): 2-8.

Pellegrini, Anthony, dan Lee Galda. The Development of School-Based Literacy: A Social Ecological Perspective. London: Routledge, 2017. https://doi.org/10.4324/9781351236263.

Rony. "Urgensi Manajemen Budaya Organisasi Sekolah Terhadap Pembentukan Karakter Peserta Didik: The Urgency of School Organizational Culture Management Against Character Building Students." Tafkir: Interdisciplinary Journal of Islamic Education 2, no. 1 (10 Februari 2021): 98-121. https://doi.org/10.31538/tijie.v2i1.26.

Sadli, Muhamad, dan Baiq Arnika Saadati. "ANALISIS PENGEMBANGAN BUDAYA LITERASI DALAMMENINGKATKAN MINAT MEMBACA SISWA DI SEKOLAH DASAR.” Jurnal Pendidikan dan Pembelajaran Dasa 6, no. 2 (2019): 2-4.

Seken, I Ketut. "Aspek Pembudayaan Dalam Pendidikan." Jurnal Pendidikan dan Pengajaran IKIP Negeri Singaraja, 2018, 7.

Setiawan, Adib Rifqi. "Pendidikan Literasi Finansial Melalui Pembelajaran Fiqh Mu'āmalāt Berbasis Kitab Kuning." Ną̧hruna 3, no. 1 (1 Maret 2020): 138-59. https://doi.org/10.31538/nzh.v3i1.522. 
Sugiyono. Memahami Penelitian Kualitatif. Bandung: Alfabeta, 2005.

Tajudin, Ahmad, dan Andika Aprilianto. "Strategi Kepala Madrasah..Dalam Membangun Budaya Religius Peserta Didik." Munaddhomah: Jumal Manajemen Pendidikan Islam 1, no. 2 (25 September 2020): 101-10. https://pasca.jurnalikhac.ac.id/index.php/munaddhomah/article/view/34.

Teguh, Mulyo. "Gerakan Literasi Sekolah Dasar." Jurnal Pendidikan Dasar Flobamorata 1, no. 2 (2020).

Wahyu, Andika. "Surabaya deklarasikan sebagai kota literasi," 2014.

Wang, Li. "Curriculum and Curriculum Integration of Information Literacy in Higher Education.” Dalam Developing People?s Information Capabilities: Fostering Information Literacy in Educational, Workplace and Community Contexts, 8:31-49. Library and Information Science 8. Emerald Group Publishing Limited, 2013. https://doi.org/10.1108/S18760562(2013)0000008007.

Whitley, Jessica, J. David Smith, Tracy Vaillancourt, dan Jennifer Neufeld. "Promoting Mental Health Literacy Among Educators: A Critical Aspect of School-Based Prevention and Intervention." Dalam Handbook of School-Based Mental Health Promotion: An EvidenceInformed Framework for Implementation, disunting oleh Alan W. Leschied, Donald H. Saklofske, dan Gordon L. Flett, 143-65. The Springer Series on Human Exceptionality. Cham: Springer International Publishing, 2018. https://doi.org/10.1007/978-3-319-89842-1_9.

Wiedarti, Pangesti. Gerakan Literasi Sekolah. Disunting oleh Desain Induk. Jakarta: Direktorat Jendral Pendidikan Dasar dan Menengah Kementrian Pendidikan dan Kebudayaan., 2016. 